\title{
Mengembangkan Keterampilan Menyimak Anak Usia Dini melalui Permainan Blind Ball
}

\author{
Ayure Cusnaki ${ }^{1}$, Amir Syamsudin ${ }^{1}$ \\ Pendidikan Anak Usia Dini, Universitas Negeri Yogyakarta, Indonesia(1) \\ DOI: $\underline{10.31004 / o b s e s i . v 6 i 4.1994}$
}

\begin{abstract}
Abstrak
Menyimak merupakan keterampilan bahasa pertama yang dimiliki oleh manusia dan modal awal seseorang untuk berkomunikasi. Penelitian bertujuan untuk mengetahui seberapa besar pengaruh permainan blind ball terhadap keterampilan menyimak anak usia dini. Sampel dalam penelitian berjumlah 24 siswa usia 5-6 tahun. Penentuan pengambilan sampel menggunakan purposive sampling. Penelitian ini menggunakan pendekatan kuantitatif dengan metode eksperimen jenis quashi experimental.. Teknik pengumpulan data menggunakan tes dan observasi. Berdasarkan hasil analisis data yang dilakukan, diperoleh rata-rata hasil tes kelompok eksperimen menggunakan permainan blind ball adalah 83,33 dan rata-rata hasil tes kelompok kontrol dengan kegiatan konvensional adalah 73,43. Hasil analisis data menunjukkan bahwa terdapat perbedaaan kemampuan menyimak anak sebelum dan sesudah diberikan perlakuan permainan blindball. Berdasarkan hasil penelitian dapat disimpulkan bahwa penggunaan permainan blind ball dapat meningkatkan kemampuan menyimak anak usia dini.
\end{abstract}

Kata Kunci: permainan; blind ball; keterampilan menyimak; anak usia dini; kuasi eksperimen

\begin{abstract}
Listening is the first language skill that had by humans and one's pondation to communicate. This study aimed to determine how much influence the blind ball game has on listening skills in early childhood. The sample in this study amointed to 24 students age 5-6 years. The determination of the sample used the purposive sampling. This study used a quantitative approach with a quashi experimental type of experimental method. (tambahan)Data collection techniques used tests and observations. Based on the results of the data analysis, the average test results of the experimental group using the blind ball game were 83.33 and the average test results of the control group using conventional activities were 73.43. The results of data analysis showed that there were differences in children's listening skills before and after being treated with blindball games. Based on the results of the study, it can be concluded that the use of blind ball games can improve listening skills of early childhood.
\end{abstract}

Keywords: game; blind ball; listening skill; early childhood; quashi experiment.

Copyright (c) 2022 Ayure Cusnaki, Amir Syamsudin

$\triangle$ Corresponding author :

Email Address : ayurecusnaki0496@gmail.com (Yogyakarta, Indonesia)

Received 23 October 2021, Accepted 16 January 2022, Published 23 January 2022 


\section{PENDAHULUAN}

Keterampilan Menyimak memegang peranan yang sangat penting dalam kehidupan manusia, karena keterampilan menyimak dasar untuk mengusai sesuatu sebelum anak memiliki keterampilan untuk berbicara, membaca, dan menulis, anak terlebih dahulu menyimak dari apa yang ada di sekitarnya (Ifadah, 2020). Menyimak merupakan keterampilan bahasa pertama yang dimiliki oleh manusia dan modal awal seseorang untuk berkomunikasi, memahami,menilai dan mengintervensikan sesuatu (Jalongo, 2010; Kendeou et al., 2006) .

Menyimak adalah suatu proses kegiatan mendengar yang dilakukan dengan sengaja, penuh perhatian, dan pemahaman, apresiasi serta interpretasi untuk memperoleh informasi atau pesan serta memahami makna komunikasi yang terkandung dalam lambang lisan yang disimak (Tarigan, 2017). Menyimak berarti mendengarkan baik-baik dengan penuh konsentrasi atau perhatian apa yang disampaikan orang lain (Weger et al., 2010). Kegiatan meyimak bertujuan untuk mendapatkan pemahaman yang jelas dari pesan yang disampikan (McNaughton et al., 2008). Pemrolehan bahasa dari keterampilan menyimak yang dimiliki oleh anak sangat berpengaruh terhadap penguasaan bahasa dan perkembangan kognitif anak, sehingga pentingnya memberikan masukan bahasa sebanyak mungkin kepada anak-anak melalui kehiatan sehari-hari (Zimmerman et al., 2009). Menyimak melibatkan proses kerja otak manusia yang digunakan untuk berifikir dan proses pengolahan tersebut dapat menyampaikan hasil pemikiran atau penalarannya sikap, dan perasaaanya, mampu bergaul, mencari informasi memalui kemampuan bahasa yang dimilikinya (Saodi et al., 2021).

Kemampuan menyimak seseorang dapat terlihat dalam suatu proses kegiatan mendengarkan lambang lisan, apresiasi, pemahaman, dan interprestasi untuk mendapatkan informasi, menangkap pesan yang disampaikan melalui bahasa lisan. Kemampuan menyimak ini dapat meningkat terus menerus jika dilatih dan diberikan stimulasi yang tepat (Rachmi, 2015). Oleh karena itu, dapat disimpulkan bahwa semakin banyak anak-anak mendengarkan dan memperoleh kosakata baru, kalimat pola, intonasi, dan sebagainya, semakin banyak kemampuan bahasa mereka berkembang (Eriani \& Dimyati, 2019).

Pentingnya keterampilan menyimak dalam proses komunikasi bukan hanya memiliki berbagai manfaat, tetapi juga menempati ruang paling besar dalam aktifitas komunikasi. Penelitian yang menunjukkan pentingnya keterampilan menyimak pernah dilakukan oleh Adler (Hermawan, 2012) yang melakukan penelitian tentang aktifitas keterampilan berbahasa dengan hasil 53\% aktivitas komunikasi didominasi oleh menyimak, sedangkan menulis 14\%, berbicara $16 \%$ dan membaca $17 \%$.

Kenyataan di lapangan berdasarkan hasil penelitian (Zein \& Puspita, 2020) fakta lapangan pada tujuh TK di kota padang menemukan beberapa permasalahan pada anak usia 5-6 tahun. Pembelajaran lebih terfokus pada pengalaman membaa-menulis, kegiatan menggambar dan mewarnai,sehingga aspek menyiman sering terabaikan. Selain itu penelitian (Fauziddin, 2017) menjelaskan bahwa penyebab rendahnya kemampuan bahasa anak karena kurang percaya diri dan anak tidak bisa melakukan kegiatan yang menarik dalam belajar. Penelitian yang sama jugadilakukan (Kim \& Phillips, 2014) menyatakan bahwa aktifitas membaa lebih sering dilakuakn disekolah yaitu $58 \%$ dari pada aktifitas menyimak $8 \%$

Berdasarkan observasi di Taman Kanak-kanak Pertiwi I Kantor Gubernur Padang ditemukan bahwa kurangnya kegiatan yang dirancang guru untuk mengembangkan kemampuan menyimak anak karena penekananan pembelajaran lebih kepada pengajaran membaca dan menulis, sehingga kemampuan menyimak anak masih belum berkembang secara optimal. Terdapat $53 \%$ anak yang belum bisa mengulang kembali apa yang telah disampaikan guru, anak kesulitan menjelaskan pembelajaran yang telah dipelajari sebelumnya dan kegiatan untuk mengembangkan kemampuan menyimak anak masih belum terencana dengan baik dalam suatu kegiatan pembelajaran. 
Oleh karena itu perlu adanya strategi pembelajaran yang tepat, inovatif, dan menyenangkan, salah satu strategi pembelajaran yang dapat digunakan yaitu melalui kegiatan bermain. Melalui kegiatan bermain anak membangun pengetahuan dan pengalaman mereka, karena bermain memberikan kesempatan kepada anak untuk terlibat aktif dalam suatu proses pembelajaran. Bermain merupakan suatu proses terjadi dengan sendirinya atau alamiah yang dilakukan oleh anak-anak atas keinginan sendiri untuk mengungkapkan konflik dirinya yang tidak disadari guna memperoleh kesenangan dan kepuasaan (Yulianty, 2010). Bermain merupakan sarana untuk menstimulasi pertumbuhan dan perkembangan anak usia dini. Bermain dapat mengembangkan kemampuan berbahasa bagi anak karena bermain menyediakan ruang dan waktu untuk saling berinteraksi, mendengarkan dan bertukar pendapat dengan orang lain (Cendana \& Suryana, 2021). Salah satu kegiatan bermain yang dapat mengembangkan kemampuan mendengar anak adalah permainan blind ball atau bola buta.

Blind ball merupakan suatu permainan mencari bola atau benda dengan mata tertutup yang dibantu oleh seorang pemandu dalam mengarahkan permainan (Aryani, 2014) . blind ball merupakan suatu permainan yang dapat melatih konsentrasi pendengaran pada anak karena melalui permainan anak akan berkonsentrasi atau menyimak apa yang disampaikan oleh seorang leader (Madyawati, 2005). Pada penelitian ini permainan blind ball dimodifikasi untuk memberikan ide baru dalam menyajikan permaianan yang menarik untuk menstimulasi perkembangan menyimak anak. pada permaiananini anak mencari bola dengan cara menutup mata. Setiap bola diberikan gambar sebagai evaluasi dalam permainan. langkah pemainan blind ball adalah; 1) Guru memilih satu orang anak yang akan menjadi sibuta untuk bermain blind ball, setelah itu ditutup matanya dengan menggunakan kain. 2) Guru memposisikan bola di arena permainan, yang akan nantinya akan dikumpulkan oleh anak. 3) Guru menginstruksikan atau mengarahkan pemain atau si buta untuk mencari bola dengan cara meneriakan arah yang harus dituju oleh si buta. 4) Sibuta harus mendengar dengan cermat atau menyimak apa yang diinstruksikan oleh guru agar si buta dapat mencapai tujuan yang diinginkan yaitu menemukan bola. 5) Apabila bola telah ditemukan maka guru menjelaskan keterangan bola yang telah didapat, anak harus menyimak apa disampaikan guru karena pada akhir permainan guru akan menanyakan kembali apa yang telah dijelaskan. 6) Setelah itu permainan diulang kembali sampai batas waktu permainan habis. 7) Guru melakukan evaluasi kepada anak, untuk mengetahui bagaimana kemampuan menyimak anak ketika diberikan permainan blindball.

\section{METODOLOGI}

Penelitian ini menggunakan pendekatan kuantitatif dengan metode eksperimen dengan jenis Quasi Eksperimental. Jenis Quashi experimental ini digunakan karena para peneliti tidak memiliki kebebasan untuk memanipulasi subjek yang berarti bahwa kelompok acak biasanya digunakan sebagai dasar untuk membentuk kelompok eksperimen dan kontrol. Desain penelitian yang digunakan adalah non equivalent control group design yang bertujuann untuk mengetahui pengaruh variabel bebas terhadap variabel terikat setelah dilaksanakan permainan blind ball. Tujuan dari penelitian ini adalah untuk mengetahui pengaruh permainan blind ball terhadap keterampilan menyimak anak usia dini di Taman Kanak-kanak Pertiwi I Kantor Gubernur Padang. Sampel dalam penelitian ini adalah siswa Taman Kanak-Kanak Pertiwi I Kantor Gubernur Padang dengan jumlah 24 orang. Teknik pengambilan sampel yang digunakan adalah teknik purposive sampling. Purposive sampling adalah teknik penentuan sampel dengan pertimbangan tertentu (Sugiyono, 2017). Alasan menggunakan purposive sampling adalah diperlukannnya dua kelas yang homogen kemampuan menyimak serta mewakili karakteristik populasi. Pada penelitian ini kelas yang dijadikan sampel adalah kelas B1 sebanyak12 orang anak sebagai kelas Eksperimen dan kelas B4 sebanyak 12orang anak sebagai kelas kontrol. 
Langkah-langkah dalam melakukan penelitian ini adalah (1) menentukan sampel penelitian yang akan digunakan (2) memberikan pretest untuk menentukan kemampuan menyimak awal anak (3) memberikan perlakuan dengan menggunakan permainan blind ball. Berikut adalah bagan langkah-langkah dalam melakukan penelitian. Desain penelitian dapat dilihat pada gambar 1.

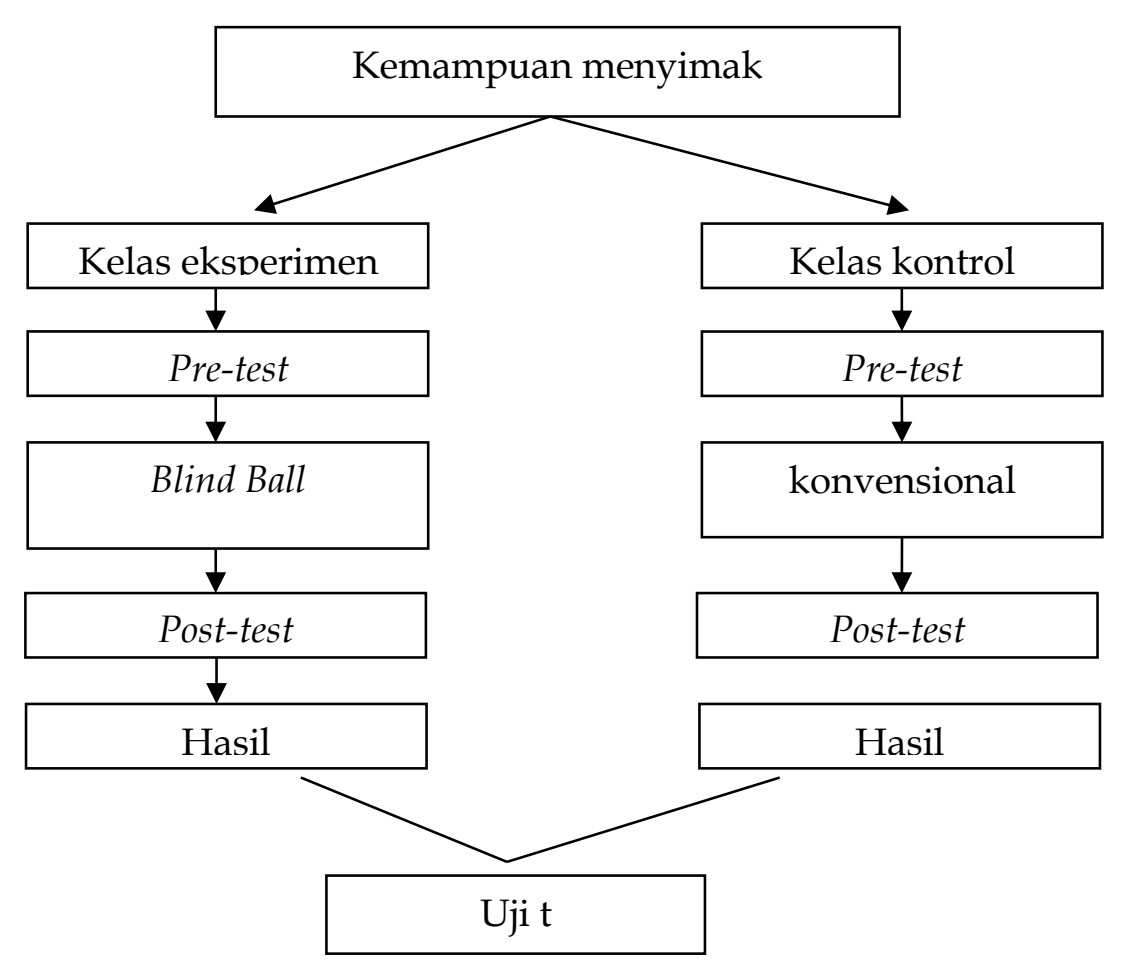

Gambar. 1 Desain Penelitian

Indikator dan istrumen dalam penelitian ini dikembangkan dari 4 aturan mendengarkan menurut Liz Spooner \& Jacqui Woodcock (2010) yang dikombinasikan dengan pendapat para ahli (Tarigan,2008; Nurjamal,2011; Jolongo, 2007) dan kurikulum 2013 lalu digambarkan sebagai rubrik penilaian untuk menentukan kriteria kriteria ketercapaian kemampuan menyimak anak.

Tabel 1. Indikator penilaian kamapuan mendengarkan anak usia 5-6 tahun



Teknik pengumpulan data yang digunakan adalah tes. Tes dilakukan untuk melihat sejauh mana perubahan pengetahuan anak setelah diberikan perlakuan dengan menggunakan permainan blind ball. Teknik analisis data yang digunakan dalam penelitian ini adalah mebandingkan perbedaan dari rata- rata nilai, namun sebelum itu melakukan uji normalitas dan uji homogenitas kemudian dilakukan uji t-tes. Pelaksanaan penelitian sebanyak 5 kali 
pertemuan. Pertemuan pertama untuk melakukan pretest pada kelompok eksperimen dan kelompok kontrol, pertemuan ke 2,3,dan 4 diberikan perlakukan pada kelas ekperimen dengan permainan blind ball, sedangkan pada kelas kontrol dengan permainan konvensional.pada pertemuan ke lima dilakukan posttest pada kedua kelompok untuk melihat bagaimana pengaruh treatment terhadap kemampuan menyimak anak usia 5-6 tahun.

\section{HASIL DAN PEMBAHASAN}

Penelitin ini bertujuan untuk mengetahui pengaruh permainan blindball terhadap kemampuan menyimak anak usia 5-6 tahun. Teknik analisi data yang digunakan adalah uji ttest, yaitu membandingkan nilai rata-rata kelas kontrol dengan kelas eksperimen.. Berikut data hasil nilai pretest kemampuan menyimak anak kelas eksperiemen dan kelas kontrol.

Tabel 2. Rekapitulasi Hasil Pre-test Kemampuan Menyimak Anak di Kelas Eksperimen dan Kelas Kontrol

\begin{tabular}{lll}
\hline \multirow{2}{*}{ Variabel } & \multicolumn{2}{c}{ Pembelajaran } \\
\cline { 2 - 3 } & \multicolumn{1}{c}{ Eksperimen B4 } & \multicolumn{1}{c}{ Kontrol B2 } \\
\hline N & 12 & 12 \\
Nilai tertinggi & 87,50 & 81,25 \\
Nilai terendah & 56,25 & 56,25 \\
Jumlah nilai & 843,75 & 831,25 \\
Median & 65,55 & 68,25 \\
Rata-rata & 70,31 & 69,27 \\
SD & 9,24 & 9 \\
SD & 85,45 & 81,11 \\
\hline
\end{tabular}

Hasil pre-test terlihat bahwa rata-rata kelas eksperimen yaitu 70,31 dan rata-rata kelas kontrol yaitu 69,27. Untuk menarik kesimpulan hasil penelitian dilakukan uji hipotesis dengan menggunakan uji t. Sebelum melakukan uji t terlebih dahulu dilakukan uji normalitas dan uji homogenitas terhadap hasil penelitian.

Tabel 3. Hasil Perhitungan Uji Liliefors Kelas Eksperimen dan Kelas Kontrol (Pretest)

\begin{tabular}{ccccccc}
\hline No & Kelas & N & A & $\mathbf{L}_{0}$ & $\mathbf{L}_{\mathbf{t}}$ & Keterangan \\
\hline 1 & Eksperimen & 12 & 0,05 & 0,2095 & 0,242 & Normal \\
\hline 2 & Kontrol & 12 & 0,05 & 0,1751 & 0,242 & Normal
\end{tabular}

Berdasarkan tabel 3 terlihat bahwa pada kelas eksperimen nilai Lhitung 0,2095 lebih kecil dari $\mathrm{L}_{\text {tabel }} 0,242$ untuk $\mathrm{a}=0,05$. Dengan demikian, nilai kelompok eksperimen berasal dari data yang berdistribusi normal. Untuk kelas kontrol, diperoleh L hitung $_{0,1751}$ lebih kecil dari $\mathrm{L}_{\text {tabel }}$ 0,242 untuk $a=0,05$. Ini berarti bahwa data kelompok kontrol berasal dari data yang berdistribusi normal.

Tabel.4 Hasil Uji Homogenitas Kelas Eksperimen dan Kelas Kontrol (pre-test)

\begin{tabular}{lcccc}
\hline \multicolumn{1}{c}{ Kelas } & $\mathrm{A}$ & $X^{2}$ hitung & $X^{2}$ tabel & Kesimpulan \\
\hline $\begin{array}{l}\text { Eksperimen } \\
\text { Kontrol }\end{array}$ & 0,05 & 0,273 & 3,841 & Homogen \\
\hline
\end{tabular}

Dari tabel 4 terlihat bahwa $X^{2}$ hitung kelas eksperimen dan kelas kontrol lebih kecil dari $X^{2}$ tabel $\left(X^{2}\right.$ hitung $<X^{2}$ tabel $)$, berarti kelas eksperimen dan kelas kontrol memiliki varians yang homogen. Setelah diketahui data berdistribusi normal dan mempunyai varians homogen. 
Tabel 5 Hasil Perhitungan Pengujian dengan t-test

\begin{tabular}{clccccc}
\hline No & Kelompok & $\mathbf{N}$ & $\begin{array}{c}\text { Hasil } \\
\text { Rata-rata }\end{array}$ & $\mathbf{t}_{\text {hitung }}$ & $\begin{array}{c}\mathbf{t}_{\text {tabel }} \\
\text { a 0,05 }\end{array}$ & Keputusan \\
\hline $\mathbf{1}$ & Eksperimen & 12 & 70,31 & 2,0434 & 2,07387 & Tolak $\mathrm{H}_{0}$ \\
$\mathbf{2}$ & Kontrol & 12 & 69,27 & & & \\
\hline
\end{tabular}

$\mathrm{T}$ tabel untuk taraf nyata a 0,05 didapat harga $t_{\text {tabel }} 2,07387$, maka dapat dikatakan bahwa pada taraf nyata o $0,05 \mathrm{t}$ hitung lebih kecil dari pada $\mathrm{t}$ tabel.dengan demikian hipotesis $\mathrm{H}_{1}$ diterima atau $\mathrm{H}_{0}$ ditolak (tabel 5). Dapat disimpulkan bahwa terdapat perbedaan yang signifikan antara hasil prestest anak di kelas eksperimen dan kelas kontrol dalam perkembangan kemampuan menyimak anak.

Tabel 6 Rekapitulasi Hasil Post-test Kemampuan Menyimak Anak di Kelas Eksperimen dan Kelas Kontrol

\begin{tabular}{ccc}
\hline \multirow{2}{*}{ Variabel } & \multicolumn{2}{c}{ Pembelajaran } \\
\cline { 2 - 3 } & Eksperimen B1 & Kontrol B4 \\
\hline N & 12 & 12 \\
Nilai tertinggi & 93,75 & 87,5 \\
Nilai terendah & 62,5 & 56,25 \\
Jumlah nilai & 1012,5 & 881,25 \\
Median & 84,5 & 72,05 \\
Rata-rata & 83,3 & 73,43 \\
SD & 9,65 & 9,64 \\
SD & 35,80 & 93,07 \\
\hline
\end{tabular}

Hasil pre-test terlihat bahwa rata-rata kelas eksperimen yaitu 83,33 dan rata-rata kelas kontrol yaitu 73,43. Uji normalitas kelas eksperimen dan kelas kontrol diperoleh harga Lo dan L1 pada taraf nyata 0,05 untuk $\mathrm{N}=12$ seperti pada tabel 7 .

Tabel 7 Hasil Perhitungan Uji Liliefors Kelas Eksperimen dan Kelas Kontrol (post-test)

\begin{tabular}{clccccc}
\hline No & Kelas & $\mathbf{N}$ & $\mathbf{A}$ & $\mathbf{L}_{0}$ & $\mathbf{L}_{\mathbf{t}}$ & Keterangan \\
\hline 1 & Eksperimen & 12 & 0,05 & 0,1401 & 0,242 & Normal \\
2 & Kontrol & 12 & 0,05 & 0,1582 & 0,242 & Normal \\
\hline
\end{tabular}

Berdasarkan tabel 6 dann 7 terlihat bahwa pada kelas eksperimen nilai $L_{h i t u n g} 0,1401$ lebih kecil dari $\mathrm{L}_{\text {tabel }} 0,242$ untuk $\alpha=0,05$. Dengan demikian, nilai kelompok eksperimen berasal dari data yang berdistribusi normal. Untuk kelas kontrol, diperoleh $\mathrm{L}_{\text {hitung }}$ 0,1582 lebih kecil dari $\mathrm{L}_{\text {tabel }} 0,242$ untuk $a=0,05$. Ini berarti bahwa data kelompok kontrol berasal dari data yang berdistribusi normal.

Tabel.8 Hasil Uji Homogenitas Kelas Eksperimen dan Kelas Kontrol (post-test)

\begin{tabular}{lcccc}
\hline \multicolumn{1}{c}{ Kelas } & $\mathrm{A}$ & $X^{2}$ hitung & $X^{2}$ tabel & Kesimpulan \\
\hline $\begin{array}{l}\text { Eksperimen } \\
\text { Kontrol }\end{array}$ & 0,05 & 0,0744 & 3,841 & Homogen \\
\hline
\end{tabular}

Dari tabel 8 terlihat bahwa $X^{2}$ hitung kelas eksperimen dan kelas kontrol lebih kecil dari $X_{\text {tabel }}^{2}\left(X^{2}{ }_{\text {hitung }}<X^{2}\right.$ tabel $)$, berarti kelas eksperimen dan kelas kontrol memiliki varians yang homogen. 
Tabel 9 Hasil Perhitungan Pengujian dengan t-test

\begin{tabular}{clccccc}
\hline No Kelompok & $\mathbf{N}$ & $\begin{array}{c}\text { Hasil } \\
\text { Rata-rata }\end{array}$ & $\mathbf{t}_{\text {hitung }}$ & $\begin{array}{c}\mathrm{t}_{\text {tabel }} \\
\mathbf{a} \mathbf{0 , 0 5}\end{array}$ & Keputusan \\
\hline $\mathbf{1}$ & Eksperimen & 12 & 83,3 & 2,0414 & 2,07387 & Tolak $\mathrm{H}_{0}$ \\
$\mathbf{2}$ & Kontrol & 12 & 73,43 & & & \\
\hline
\end{tabular}

Berdasarkan tabel $9 \mathrm{df}$ untuk taraf nyata a 0,05 didapat harga $t_{\text {tabel }} 2,07387$, maka dapat dikatakan bahwa hipotesis $\mathrm{H}_{1}$ diterima atau $\mathrm{H}_{0}$ ditolak. Dapat disimpulkan bahwa terdapat perbedaan yang signifikan antara hasil post-test (hasil akhir) anak di kelas eksperimen dan kelas kontrol dalam perkembangan kemampuan menyimak anak.

Dari penelitian yang dilakukan dapat dilihat perbedaan rata-rata nilai pada kelas ekspermen dan kelas kontrol sebelum dan sesudah diberikannya perlakuan. Sebelum diberikan perlakuan nilai rata kelas kontrol adalah 69,27 sedangkan pada kelas eksperimen adalah 70,31. Setelah diberikan perlakuan pada kalas eksperimen dengan menggunakan permainan blindball kemampuan meyimak anak meningkat menjadi 83,3, pada kelas kontrol dengan menggunakan metode konvesional 73,34. Dari analisis data adanya perbandingan hasil kelas eksperimen dan kelas kontrol. Hasil penelitian menunjukan bahwa dengan adanya permainan blindball dapat meningkatkan kemampuan menyimak anak usia dini.

Hal ini juga didukung oleh penelitian (Wurzel, 1990)permainan dengan mata tertutup seperti orang buta merupakan suatu permainan yang menarik karena membatasi kinerja pemain dalam melakukan hal namun dapat menjadi refleksi untuk yang mendalamuntuk meningkatkan fokus perhatian yang mendalam. Penelitian yang dilakukan oleh (Pahrul \& Amalia, 2020) mengenai penerapan permainan bermain dalam lingkaran untuk mengembangkan aspek kognitif anak, dimana dapat melatih daya ingat anak, dapat melatih kemampuan mendengar, kemampuan memecahkan masalah, serta kemampuan menirukan. Selain aspek perkembangan kognitif, bermain juga dapat meningkatkan perkembangan bahasa anak. Bahasa merupakan alat komunikasi dan bersosialisasi. Saat anak memasuki pendidikan Taman Kanak-kanak, anak akan dihadapkan pada halhal yang mengharuskan anak bersosialisasi menggunakan bahasa (Fika et al., 2019). Demikaian halnya pelaksaanan kegiatan bermaian dapat seara efektitif meningkatkan kemampuan menyimak anak usia dini (Budyawati \& Hartanto, 2017)

Dalam permainan ini terjadi proses mendengarkan atau proses menangkap suara oleh telinga. Pemain harus sungguh-sungguh mendengarkan apa yang disampaikan oleh leader sehingga dapat memenangkan pertandingan. Kegiatan ini dapat melatih kemampuan menangkap bahasa atau menyimak pada anak serta membiasakan diri untuk mendengar dengan penuh konsentrasi.

Permainan bind ball dimainkan secara berkelompok 2-6 orang dan tempat pelaksanaanya bisa di dalam atau luar ruangan. Peralatan yang digunakan dalam permainan ini sangat sederhana yaitu bola plastik dan kain sebagai penutup mata. Permainan blind ball selain dapat mengembangkan kemampuan menyimak pada anak usia dini permainan ini juga dapat melatih ketangkasan, indra peraba, melatih gerak kinestetik, mengembangkan kemampuan sosial dan kognitif pada anak usia dini.

\section{SIMPULAN}

Berdasarkan hasil analisis data penelitian yang telah dilakukan, kemampuan menyimak anak di kelas kontrol (B4) yaitu dengan nilai rata-rata kelas 83,33 di kelas eksperimen, dan 73,43 di kelas kontrol. Setelah dilakukan uji hipotesis diperoleh hasil $t_{\text {hitung }}>t$ tabel dimana 2,4014 > 2,07387 yang dibuktikan dengan taraf signifikan a 0,05 ini berarti terdapat perbedaan yang signifikan antara hasil kemampuan menyimak anak pada kelas eksperimen yang dilakukan dengan permainan blind ball dibandingkan dengan kelas kontrol.. Dengan demikian, permainan blind ball berpengaruh terhadap kemampuan menyimak anak di Taman Kanak- kanak Pertiwi I Kantor Gubernur Padang. 


\section{UCAPAN TERIMA KASIH}

Terimakasih kepada pembimbing yang sudah memberikan masukan dalam penulisan artikel ini serta semua pihak yang telah membantu penulis sehingga penelitian ini dapat dipublikasikan. Terimakasih juga disampaikan kepada tim editor Jurnal Obsesi yang telah memberikan saran, kritik, dan rekomendasi untuk perbaikan artikel ini.

\section{DAFTAR PUSTAKA}

Budyawati, L. P. I., \& Hartanto, W. (2017). Implementasi Metode Bermain Peran Untuk Peningkatan Kemampuan Menyimak Anak Usia Dini Di Paud Sekarwangi Desa Bangorejo Banyuwangi 2017. Junal Pendidikan Ekonomi: Jurnal Ilmiah Ilmu Pendidikan, Ilmu Ekonomi Dan Ilmu Sosial, 11(2), 24. https://doi.org/10.19184/jpe.v11i2.6331

Cendana, H., \& Suryana, D. (2021). Pengembangan Permainan Tradisional untuk Meningkatkan Kemampuan Bahasa Anak Usia Dini. Jurnal Obsesi : Jurnal Pendidikan Anak Usia Dini, 6(2), 771-778. https://doi.org/10.31004/obsesi.v6i2.1516

Erfin Yudhi Aryani. (n.d.). Pendamping kegiatan anak. Naafi' Book Media.

Eriani, E., \& Dimyati, D. (2019). Story Telling Using Madihin: Learning Methods for Early Childhood Listening Skills. Jurnal Obsesi : Jurnal Pendidikan Anak Usia Dini, 3(2), 303. https://doi.org/10.31004/obsesi.v3i2.172

Fauziddin, M. (2017). Upaya Peningkatan Kemampuan Bahasa Anak Usia 4-5 Tahun melalui Kegiatan Menceritakan Kembali Isi Cerita di Kelompok Bermain Aisyiyah Gobah Kecamatan Tambang. Jurnal Obsesi: Jurnal Pendidikan Anak Usia Dini, 1(1), 42. https://doi.org/10.31004/obsesi.v1i1.30

Fika, Y., Meilanie, S. M., \& Fridani, L. (2019). Peningkatan Kemampuan Bicara Anak melalui Bermain Peran Berbasis Budaya. Jurnal Obsesi : Jurnal Pendidikan Anak Usia Dini, 4(1), 50. https://doi.org/10.31004/obsesi.v4i1.229

Hermawan, H. (2012). Ketrampilan Komunikasi Yang Terabaikan. Graha Ilmu.

Ifadah, A. S. (2020). Peningkatan Kemampuan Menyimak Anak Usia Dini Dengan Media Boneka Tongkat. JCE (Journal of Childhood Education), 4(2), 93. https://doi.org/10.30736/jce.v4i2.258

Jalongo, M. R. (2010). Listening in early childhood: An interdisciplinary review of the literature. International Journal of Listening, 24(1), 1-18. https://doi.org/10.1080/10904010903466279

Kim, Y. S., \& Phillips, B. (2014). Cognitive correlates of listening comprehension. Reading Research Quarterly, 49(3), 269-281. https:// doi.org/10.1002/rrq.74

Madyawati, L. (2005). Permainan dan Bermain Untuk Anak. Prenada.

McNaughton, D., Hamlin, D., McCarthy, J., Head-Reeves, D., \& Schreiner, M. (2008). Learning to Listen: Teaching an Active Listening Strategy to Preservice Education Professionals. Topics in Early Childhood Special Education, 27(4), 223-231. https:// doi.org/10.1177/0271121407311241

Pahrul, Y., \& Amalia, R. (2020). Metode Bermain Dalam Lingkaran dalam Pengembangan Kemampuan Kognitif Anak Usia Dini Di Taman Penitipan Anak Tambusai Kecamatan Bangkinang Kota. Jurnal Obsesi : Jurnal Pendidikan Anak Usia Dini, 5(2), 1464-1471. https://doi.org/10.31004/obsesi.v5i2.812

Rachmi, T. (2015). Pengaruh Permainan dan Kemampuan Menyimak terhadap Kemampuan Bercerita. Jurnal Pendidikan Anak Usia Dini, 9(1), 127-142. https://doi.org/10.21009/JPUD.091

Saodi, S., Musi, M. A., Manggau, A., \& Noviani, N. (2021). Metode Storytelling dengan Musik Instrumental untuk Meningkatkan Kemampuan Menyimak dan Berbicara Anak. In Jurnal Obsesi: Jurnal Pendidikan Anak Usia Dini (Vol. 6, Issue 1, pp. 163-172). https://doi.org/10.31004/obsesi.v6i1.1196 
Sugiyono. (2017). Metode Penelitian Pendidikan Pendekatan Kombinasi. In R \& D. Alfabeta (Eds.), Metode Penelitian Pendidikan Pendekatan Kuantitatif, Kualitatif Dan R\&D (p. 225).

Tarigan, H. G. (2017). Menyimak Sebagai Suatu Keterampilan Berbahasa. In Angkasa Bandung. Angkasa.

Weger, H., Castle, G. R., \& Emmett, M. C. (2010). Active listening in peer interviews: The influence of message paraphrasing on perceptions of listening skill. International Journal of Listening, 24(1), 34-49. https:// doi.org/10.1080/10904010903466311

Wurzel, B. (1990). A Ball Game for Teams of Blind and Seeing Children: Circle Goal Ball. In Adapted Physical Activity (pp. 183-187). https://doi.org/10.1007/978-3-642-74873$\underline{8 \_28}$

Yulianty, R. (2010). Permainan Yang Meningkatkan Kecerdasan Anak. Laskar Aksar.

Zein, R., \& Puspita, V. (2020). Model Bercerita untuk Peningkatan Keterampilan Menyimak dan Berbicara Anak Usia 5-6 Tahun. Jurnal Obsesi : Jurnal Pendidikan Anak Usia Dini, 5(2), 1199-1208. https://doi.org/10.31004/obsesi.v5i2.581

Zimmerman, F. J., Gilkerson, J., Richards, J. A., Christakis, D. A., Xu, D., Gray, S., \& Yapanel, U. (2009). Teaching by listening: The importance of adult-child conversations to $\begin{array}{lll}\text { language development. } \quad \text { Pediatrics, } & \text { 342-349. }\end{array}$ https://doi.org/10.1542/peds.2008-2267 